\title{
Head Space Solid Phase Micro-Extraction (HS - SPME) of volatile organic compounds produced by Sporidiobolus salmonicolor (CBS 2636)
}

\author{
Microextração em Fase Sólida (MEFS) de compostos voláteis produzidos por \\ Sporidiobolus salmonicolor (CBS 2636)
}

\author{
Eunice VALDUGA ${ }^{1}$, Alexsandra VALERIO ${ }^{1}$, Helen TREICHEL ${ }^{1 \star}$, Irajá NASCIMENTO FILHO ${ }^{2}$, \\ Agenor FÚRIGO JÚNIOR ${ }^{3}$, Marco Di LUCCIO ${ }^{1}$
}

\begin{abstract}
The aim of the present study was the assessment of volatile organic compounds produced by Sporidiobolus salmonicolor (CBS 2636) using methyl and ethyl ricinoleate, ricinoleic acid and castor oil as precursors. The analysis of the volatile organic compounds was carried out using Head Space Solid Phase Micro-Extraction (HS - SPME). Factorial experimental design was used for investigating extraction conditions, verifying stirring rate $(0-400 \mathrm{rpm})$, temperature $\left(25-60^{\circ} \mathrm{C}\right)$, extraction time (10-30 minutes), and sample volume (2-3 mL). The identification of volatile organic compounds was carried out by Gas Chromatography with Mass Spectrum Detector (GC/MSD). The conditions that resulted in maximum extraction were: $60{ }^{\circ} \mathrm{C}, 10$ minutes extraction, no stirring, sample volume of $2.0 \mathrm{~mL}$, and addition of saturated $\mathrm{KCl}$ $(1: 10 \mathrm{v} / \mathrm{v})$. In the bio-production of volatile organic compounds the effect of stirring rate $(120-200 \mathrm{rpm})$, temperature $\left(23-33^{\circ} \mathrm{C}\right), \mathrm{pH}(4.0-$ 8.0 ), precursor concentration (0.02-0.1\%), mannitol (0-6\%), and asparagine concentration (0-0.2\%) was investigated. The bio-production at $28^{\circ} \mathrm{C}, 160 \mathrm{rpm}, \mathrm{pH} 6,0$ and with the addition of $0.02 \%$ ricinoleic acid to the medium yielded the highest production of VOCs, identified as 1,4-butanediol, 1,2,2-trimethylciclopropilamine, beta-ionone; 2,3-butanodione, pentanal, tetradecane, 2-isononenal, 4-octen-3-one, propanoic acid, and octadecane.
\end{abstract}

Keywords: bio-production; Sporidiobolus salmonicolor; SPME; aroma; experimental design.

\section{Resumo}

O objetivo do presente estudo foi avaliar os compostos orgânicos voláteis produzidos por Sporidiobolus salmonicolor (CBS 2636) utilizando metil e etil ricinoleato, ácido ricinoleico e óleo de mamona como precursores. A análise dos compostos voláteis produzidos foi conduzida por Micro-Extração em Fase Sólida (MEFS). A técnica de planejamento experimental foi utilizada na avaliação das condições de extração, na qual se avaliaram a agitação (0-400 rpm), a temperatura (25-60 $\left.{ }^{\circ} \mathrm{C}\right)$, o tempo de extração (10-30 minutos) e o volume da amostra (2-3 mL). A identificação dos compostos foi realizada por Cromatografia a Gás com detecção por Espectrometria de Massas (CG/EM). As condições que resultaram na máxima extração foram: $60^{\circ} \mathrm{C}, 10$ minutos de extração, sem agitação, volume de amostra de $2,0 \mathrm{~mL}$ e adição de solução de $\mathrm{KCl}$ saturada (1:10 v/v). Na bioprodução dos compostos voláteis, o efeito da agitação (120-200 rpm), da temperatura (23-33 $\left.{ }^{\circ} \mathrm{C}\right)$, do pH $(4,0$ $8,0)$, da concentração do precursor $(0,02$ a $0,1 \%)$, da concentração de manitol $(0$ a $6 \%)$ e de asparagina $(0$ a $0,2 \%)$ foi avaliado. Na condição de $28{ }^{\circ} \mathrm{C}, 160 \mathrm{rpm}, \mathrm{pH}$ 6,0 e com a adição de $0,02 \%$ de ácido ricinoleico ao meio, foi atingida a máxima produção dos compostos voláteis, identificados como: 1,4-butanodiol, 1,2,2-trimetilciclopropilamina, beta-ionona; 2,3-butanodiona, pentanal, tetradecano, 2-isononenal, 4-octen-3-ona, ácido propanoico e octadecano.

Palavras-chave: bioprodução; Sporidiobolus salmonicolor; SPME; aroma; planejamento de experimentos.

\section{Introduction}

An aroma is a complex mixture of several volatile organic molecules such as esters, aldehydes, ketones, lactones, alcohols and others. Natural aroma compounds may be obtained by extraction of plant leaves, flowers, and fruits (XIE; SUN; YU, 2006; ZHANG; ZENG; LI, 2006; CAI; LIU; SU, 2001), but they can also be produced by several microorganisms (JANSSENS et al., 1992). However, the bio-production of aroma compounds often results in very low concentration of the Volatile Organic Compounds (VOC) in aqueous solutions.
The analysis of such dilute solutions of VOC is usually a difficult task. The recovery of the VOC from samples usually involves extraction with an organic solvent, which may imply in some loss of the product of interest and very time consuming procedures (CARASEK; PAWLISZYN, 2006).

An alternative technique for the analysis of VOCs is Solid Phase Micro-Extraction (SPME). This technique is based on the fact that the analytes present in the sample or in its Head

Recebido para publicação em 8/10/2008

Aceito para publicação em 8/7/2009 (003881)

${ }^{1}$ Departamento de Engenharia de Alimentos, Universidade Regional Integrada do Alto Uruguai e das Missões - URI, CEP 99700-000, Erechim - RS, Brasil,

E-mail:helen@uricer.edu.br

2 Departamento de Física e Quimica, Universidade de Caxias do Sul - UCS

${ }^{3}$ Departamento de Engenharia Química, Universidade Federal de Santa Catarina - UFSC

${ }^{*}$ A quem a correspondência deve ser enviada 
Space are absorbed on an extracting phase. The latter consists in a very thin polymeric film immobilised on a fused silica core (PAWLISZYN, 1999).

Three basic extraction procedures may be used in SPME: direct, Head Space, and indirect. In Head Space SPME (HSSPME) mode, the polymeric film is exposed to the gas phase that lies immediately over the liquid sample. This operation strategy is ideal in the case in which the analytes are volatile enough at the extraction temperature. Additionally, Head Space mode also protects the extracting phase from impurities and allows modification of the sample ( $\mathrm{pH}$, ionic strength, etc), without any damage to the polymeric film. Head Space SPME has an advantage of being a non-destructive technique and allows the evaluation of the samples at different experimental conditions (PAWLISZYN, 1999).

This technique has been widely used in phenolic compound analysis (BUCHHOLZS; PAWLISZYN, 1994), aroma compounds found in fruits and juices (ZHANG; ZENG; LI, 2006; LIU; YANG, 2002), volatile compounds found in plant leaves or flowers (XIE; SUN; YU, 2006; PÉREZ et al., 2002; XIONG et al., 2003; KATAOKA; LORD; PAWLISZYN, 2000; BARRIONUEVO; LANÇAS, 2001), and in the analysis of organophosphorous pesticides present in aqueous solutions (BARRIONUEVO; LANÇAS, 2001).

Only few studies dealing with the use of this technique for the analysis of aroma of fermentation broths can be found in literature. Studies about volatile organic compounds produced by Lactobacillus (GOUPRY et al., 2000), Trichoderma harzianum (FIEDLER; SCHUTZ; GEH, 2001), many species of Aspergillus and Penicillium (FIEDLER; SCHUTZ; GEH, 2001) and Staphylococci (VERGNAIS et al., 1998) are reported. The variability of yeast strains in their ability to produce volatile compounds has also been studied using SPME (MAURIELLO et al., 2009). SPME has also been applied to volatile organic compounds analysis in beer and wines (KAFKAS et al., 2005; SALINAS et al., 2004; MALLUCHOS et al., 2002).

In this context, the aim of the present study was the assessment of Volatile Organic Compounds (VOCs) produced by Sporidiobolus salmonicolor (CBS 2636) using methyl and ethyl ricinoleate, ricinoleic acid and castor oil as precursors. The analysis of VOCs was performed by Solid Phase Microextraction (SPME) using Head Space method (HS-SPME).

\section{Materials and methods}

\subsection{Bio-production of volatile organic compounds}

The inoculum was prepared by transferring a loopful of a stock culture to $100 \mathrm{~mL}$ of YM medium ( 3 g.L.- yeast extract, 3 g.L $\mathrm{L}^{-1}$ malt extract, 5 g.L. $\mathrm{L}^{-1}$ peptone and 10 g. $\mathrm{L}^{-1}$ glucose) followed by incubation at $28{ }^{\circ} \mathrm{C}, 160 \mathrm{rpm}$ for 12 hours in an orbital shaker. The cell concentration was followed by Optical Density (OD), determined in a spectrophotometer (Agilent, model 8553, SP, Brazil) at $650 \mathrm{~nm}$. The cell suspension was used as inoculum in a concentration of $2 \%(\mathrm{v} / \mathrm{v})$.
The bio-production of VOCs was carried out in $250 \mathrm{~mL}$ Erlenmeyer flasks with $100 \mathrm{~mL}$ of cultivation medium. Two media were tested in this study: MYM (modified YM) and YNB (Yeast Nitrogen Base). The modified YM medium consisted of 1 g.L. $\mathrm{L}^{-1}$ yeast extract (Vetec - RJ, Brazil), 1 g.L. $\mathrm{L}^{-1}$ malt extract (Vetec - RJ, Brazil), 0.5 g.L. $\mathrm{L}^{-1}$ bactotryptone (Difco, USA), 15 g.L $L^{-1}$ glucose, 2 g. $L^{-1}$ casaminoacid (Merck, SP, Brazil), 2 g.L. ${ }^{-1} \mathrm{KH}_{2} \mathrm{PO}_{4}$ (Synth, RS, Brazil), 0.13 g.L $\mathrm{L}^{-1} \mathrm{CaCl}_{2} \cdot 2 \mathrm{H}_{2} \mathrm{O}$ (Nuclear, RS, Brazil), 0.01 g. $\mathrm{L}^{-1} \mathrm{FeSO}_{4} \cdot 7 \mathrm{H}_{2} \mathrm{O}$ (Nuclear, RS, Brazil), and $3 \mathrm{~g} \cdot \mathrm{L}^{-1} \mathrm{MgSO}_{4} \cdot 7 \mathrm{H}_{2} \mathrm{O}$ (Synth, RS, Brazil). The YNB medium was acquired from Difco (USA) and consisted of yeast extract $\left(67 \mathrm{~g} . \mathrm{L}^{-1}\right)$, dextrose $\left(50 \mathrm{~g} . \mathrm{L}^{-1}\right)$ without aminoacids, and ammonium sulphate. Both media were tested also with supplementation with mannitol (Sigma, USA) and asparagine (Vetec, RJ, Brazil). The effect of the precursors was investigated by adding methyl ricinoleate, ethyl ricinoleate, castor oil, and ricinoleic acid (all from Brazmo, SP, Brazil, commercial grade) at the end of exponential growth phase. The composition of the fermentation media that yielded the higher amounts of VOCs is presented in Table 1.

\subsection{Head Space Solid Phase Micro-Extraction (SPME - HS)}

Prior to the extractions, the extracting fibre (Polydimethylsiloxane - PDMS $100 \mu \mathrm{m}$, Supelco, USA) was conditioned in the injector of gas chromatograph (GC/MSD, Shimadzu GC17A, QP5050A, Japan) at $250^{\circ} \mathrm{C}$ for 1 hour. For Head Space extractions, $10 \mathrm{~mL}$ Head Space vials (Supelco, USA) were used, sealed with rubber septa faced with PTFE (polytetrafluorethylene), and sealed with aluminium seal. Sample vials were constantly stirred on a magnetic stirrer and placed in a temperature controlled water bath (Nova Ética, Mod. 521-3D, SP, Brazil.

The effect of temperature, stirring rate, sample volume, and extraction time on the extraction was evaluated by a $2^{4-1}$ factorial design with 3 central points for the evaluation of experimental error. Studied factors are listed in Table 2. The results were statistically analysed using the Experimental Design tool of Statistica 6.0 (StatSoft, Inc., 2001, www.statsoft.com). The SPME fibre was exposed only after the pre-determined temperature

Table 1. Fermentation media composition based on different supplements.

\begin{tabular}{cccccc}
\hline Medium & $\begin{array}{c}\text { Precursor } \\
(\%)\end{array}$ & & Medium & $\begin{array}{c}\text { Mannitol } \\
(\%)\end{array}$ & $\begin{array}{c}\text { Asparagine } \\
(\%)\end{array}$ \\
\hline 1 & ricinoleic acid & 0.02 & MYM & 0 & 0 \\
2 & & 0.06 & MYM & 0 & 0 \\
3 & & 0.1 & MYM & 0 & 0 \\
4 & & 0.06 & YNB & 3 & 0.1 \\
5 & methyl ricinoleate & 2 & MYM & 0 & 0 \\
6 & & 8 & MYM & 0 & 0 \\
7 & & 16 & MYM & 0 & 0 \\
8 & & 5 & MYM & 0 & 0 \\
9 & ethyl ricinoleate & 8 & YNB & 3 & 0.1 \\
10 & castor oil & 0.08 & MYM & 0 & 0 \\
11 & & 0.16 & MYM & 0 & 0 \\
\hline
\end{tabular}

Incubation temperature $=28^{\circ} \mathrm{C}$, stirring rate $=160 \mathrm{rpm}, \mathrm{pH}=6.0$. 
was reached and stabilised. The exposition of the fibre to sample Head Space was carried out for a period of time determined in the experimental design.

Since some yeasts are known as producers of lactones (BLIN-PERRIN et al., 2000), a standard solution of $50 \mathrm{mg} \cdot \mathrm{L}^{-1}$ of gamma-decalactone (Aldrich, USA), dissolved in YM medium, was used in the experiments for determining the best HS-SPME conditions for the extraction of volatiles from fermentation medium.

The influence of modifiers on the extraction ability of the fibre was also tested by adding solutions of inorganic salts to the sample (KCl, $\mathrm{NaCl}, \mathrm{Na}_{2} \mathrm{SO}_{4}$, and $\mathrm{NaH}_{2} \mathrm{PO}_{4}$, Vetec, RJ, Brasil) at the ratio $1: 10(\mathrm{v} / \mathrm{v})$ and at concentrations of $5 \%(\mathrm{w} / \mathrm{v}), 25 \%$ $(\mathrm{w} / \mathrm{v})$ and saturated solution.

\subsection{Solvent extraction}

The solvent extraction of the samples was carried out using the procedure described elsewhere (MARTINS; LEITE; SILVA, 2003) with some modifications. Gamma-decalactone was extracted from samples with $10 \mathrm{~mL}$ of dichloromethane (Merck, SP, Brazil) in $40 \mathrm{~mL}$ flasks, sealed with PTFE faced rubber septa sealed with aluminium crimp seals (Supelco, USA). Samples were stirred at $150 \mathrm{rpm}$ for 2 hours. The organic phase was separated, dried with anhydrous sodium sulphate (Vetec, RJ, Brazil), and analysed by GC/MSD.

\subsection{Identification of volatile compounds}

After VOC extraction and concentration by HS-SPME, the fibre was retracted to its support and exposed in the GC injector for 10 minutes, so that the thermal desorption of the volatile organic compounds could take place. The operation parameters for chromatographic analysis were previously determined aiming

Table 2. Range of the factors investigated in the full experimental design $2^{4-1}$.

\begin{tabular}{lccc}
\hline \multicolumn{1}{c}{ Factors } & \multicolumn{3}{c}{ Levels } \\
\cline { 2 - 4 } & -1 & 0 & +1 \\
\hline Sample volume $(\mathrm{mL})$ & 2.0 & 2.5 & 3.0 \\
Stirring rate $(\mathrm{rpm})$ & 0 & 200 & 400 \\
Temperature $\left({ }^{\circ} \mathrm{C}\right)$ & 25 & 42 & 60 \\
Extraction time $($ minute) & 10 & 20 & 30 \\
\hline
\end{tabular}

at the best separation of the studied compounds, as follows: column DB-5 (30 m $\times 0.25 \mathrm{~mm} \times 0.25 \mu \mathrm{m}$, J\&W Scientific, USA); column heater temperature: $150^{\circ} \mathrm{C}$; injector temperature: $280^{\circ} \mathrm{C}$, splitless, interface temperature: $300^{\circ} \mathrm{C}$; carrier gas flow (Helium, Analytical grade): $0.6 \mathrm{~mL} /$ minute; column heating program: $150{ }^{\circ} \mathrm{C}$ for 3 minutes, increase to $220{ }^{\circ} \mathrm{C}$ (at $3{ }^{\circ} \mathrm{C} /$ minute), and increase to $250{ }^{\circ} \mathrm{C}$ (at $10^{\circ} \mathrm{C} /$ minute), remaining at this temperature for 5 minutes for column purge.

The detector voltage was set to $1.25 \mathrm{kV}$. The mass spectra of the sample constituents were compared with a spectra library (Wiley 229) compatible with chemical classes of the components under study and by the retention time related to an authentic standard of gamma-decalactone (Aldrich).

\subsection{Statistical analysis}

All analytical runs were carried out in triplicates. The experimental data was submitted to the analysis of variance (ANOVA) to determine the significant effects. The differences were analysed by the Tukey test for the comparison of means, with a confidence level of 95\%, using the software STATISTICA version 6.0 (StatSoft Inc.).

\section{Results and discussion}

\subsection{HS-SPME extraction conditions}

The matrix of the $2^{4-1}$ experimental design with the respective responses in terms of area units is presented in Table 3. The highest peak area was obtained at run 4 . The results of this experimental design were statistically analysed. The temperature of extraction was the only variable that presented a statistically significant effect $(\mathrm{p}<0.05)$. Based on these results, a new set of experimental runs was carried out to find the best extraction temperature. For this study, the other parameters were set to the -1 level (Table 4 ).

The temperature that yields the maximum extraction by the fibre was $60^{\circ} \mathrm{C}$. Higher or lower temperatures led to a decrease in the amount of the compound extracted. Pawliszyn (1999) suggests that the yield of extraction depends on the dynamic equilibrium among the three phases involved in HS-SPME: liquid, gas, and polymer film that are maintained in a closed system at constant temperature. In this case, the higher the

Table 3. Matrix of the experimental design $2^{4-1}$ and the response in terms of mean area of detected peak of gamma-decalactone.

\begin{tabular}{cccccc}
\hline Run & Volume $(\mathrm{mL})$ & Time $($ minute $)$ & Temperature $\left({ }^{\circ} \mathrm{C}\right)$ & Stirring rate $(\mathrm{rpm})$ & Mean area of the peaks $\left(10^{6} \mathrm{AU}\right)^{*}$ \\
\hline 1 & 2 & 10 & 25 & 0 & $9.8 \pm 0.17$ \\
2 & 2 & 10 & 60 & 400 & $23.1 \pm 0.23$ \\
3 & 2 & 30 & 25 & 400 & $21.7 \pm 2.00$ \\
4 & 2 & 30 & 60 & 0 & $46.5 \pm 0.84$ \\
5 & 3 & 10 & 25 & 0 & $7.1 \pm 2.80$ \\
6 & 3 & 10 & 60 & 0 & $21.1 \pm 1.40$ \\
7 & 3 & 30 & 25 & 400 & $1.8 \pm 0.13$ \\
8 & 3 & 20 & 40 & 200 & $44.3 \pm 2.60$ \\
9 & 2.5 & & & & $17.7 \pm 0.54$ \\
\hline
\end{tabular}

${ }^{*}$ means \pm standard deviation. 
temperature, the higher the amount of volatile compounds present in the Head Space, favouring the extraction. While the thermodynamic equilibrium is favourable for the analyte sorption, the polymer film will be enriched in the compound and consequently the peak area will increase. Conversely, the temperature increase also reduces the partition coefficients between the volatile compounds and the polymer films since the sorption process is exothermic. In this case, the equilibrium will be dislocated towards the Head Space (gas phase) causing the decrease detected in the mean area.

Similar results were obtained by Ibáñez et al. (1998) for the optimization of HS-SPME during the identification of volatile organic compounds of fruits (raspberry, strawberry, mango, and banana). These authors tested extractions at 30 and $60^{\circ} \mathrm{C}$, and extraction times of 15 and 30 minutes. Extractions carried out at $60{ }^{\circ} \mathrm{C}$ for 30 minutes yielded the highest amount of volatile compounds using a PDMS fibre of $100 \mu \mathrm{m}$.

The effect of addition of inorganic salts on the extraction of gamma-decalactone is presented in Table 5. The addition of saline solutions to the sample seems to improve the analyte extraction by SPME fibre. The best results were obtained with saturated $\mathrm{KCl}$. However, good results could also be achieved with $5 \% \mathrm{Na}_{2} \mathrm{SO}_{4}$ saturated $\mathrm{NaCl}$, and $25 \% \mathrm{Na}_{2} \mathrm{SO}_{4}$. Depending on the analyte, the sensibility of the method may be improved by the reduction of $\mathrm{pH}$, which keeps the neutral form of the compounds, or by the addition of salts, which will concur with organic ions for the solvation of water molecules. Thus, the organic compounds will not be solvated by water and can be extracted more easily (BUCHHOLZ; PAWLISZYN, 1994).

The results in Table 6 show that the SPME with addition of saturated $\mathrm{KCl}$ is more sensible than the solvent extraction

Table 4. Mean area of peaks as a function of extraction temperature.

\begin{tabular}{ccc}
\hline Run & Temperature $\left({ }^{\circ} \mathrm{C}\right)$ & Mean area $\left(10^{6} \text { U.A. }\right)^{*}$ \\
\hline 1 & 50 & $25.9 \pm 7.7^{\mathrm{c}}$ \\
2 & 60 & $47.1 \pm 3.4^{\mathrm{a}}$ \\
3 & 70 & $32.5 \pm 8.6^{\mathrm{b}}$ \\
4 & 80 & $3.0 \pm 1.7^{\mathrm{d}}$ \\
\hline
\end{tabular}

*means \pm standard deviation. Values followed by same superscript letters are not significantly different $(\mathrm{p}<0.05)$ (Tukey Test).

Table 5. Effect of addition of inorganic salts on mean peak area.

\begin{tabular}{lcc}
\hline Run & Salt solution $(\% \mathrm{w} / \mathrm{w})$ & Mean area $\left(10^{6} \text { U.A. }\right)^{*}$ \\
\hline 1 & $5 \% \mathrm{KCl}$ & $48.2 \pm 3.5^{\mathrm{d}}$ \\
2 & $25 \% \mathrm{KCl}$ & $56.5 \pm 1.3^{\mathrm{cb}}$ \\
3 & Saturated $\mathrm{KCl}$ & $66.3 \pm 4.0^{\mathrm{a}}$ \\
4 & $5 \% \mathrm{NaCl}$ & $55.2 \pm 0.9^{\mathrm{cb}}$ \\
5 & Saturated NaCl & $59.8 \pm 2.2^{\mathrm{ac}}$ \\
6 & $5 \% \mathrm{Na}_{2} \mathrm{SO}_{4}$ & $61.5 \pm 3.8^{\mathrm{ab}}$ \\
7 & $25 \% \mathrm{Na}_{2} \mathrm{SO}_{4}$ & $59.3 \pm 0.7^{\mathrm{abc}}$ \\
8 & ${\text { Saturated } \mathrm{Na}_{2} \mathrm{SO}_{4}}_{9}$ & $52.1 \pm 2.0^{\mathrm{d}}$ \\
9 & $25 \% \mathrm{NaH}_{2} \mathrm{PO}_{4}$ & $54.1 \pm 1.5^{\mathrm{c}}$ \\
10 & No salt & $47.1 \pm 1.5^{\mathrm{d}}$ \\
\hline
\end{tabular}

${ }^{*}$ means \pm standard deviation. Values followed by same superscript letters are not significantly different $(\mathrm{p}<0.05)$ (Tukey Test). technique (1.8 times higher). This observation agrees, for instance, with the reported results of the comparison of SPME and solvent extraction with 6-pentyl- $\alpha$-pyrone produced by Trichoderma harzianum (MARTINS; LEITE; SILVA, 2003).

\subsection{Bio-production of volatile organic compounds}

The compounds that were isolated and identified in the medium after the bio-reaction are listed in Table 7 for the different media compositions that were presented in Table 1. The different chromatographic profiles obtained are related to the media composition, mainly to the carbon source. The same behaviour was reported by Welsh, Murray and Willians (1989) that observed that Ceratocystis moniliformis produces banana, citrus, and peach flavour, depending on media composition. After 120 hours, $50 \mu \mathrm{g}$ of monoterpenes.mg ${ }^{-1}$ of cells could be obtained. The yield was increased with a temperature increase using high concentrations of asparagines as nitrogen source.

The highest yield in VOCs was obtained using medium 1 (Table 7) with $0.2 \%$ of ricinoleic acid. The major compounds produced in this condition were aldehydes and ketones. The compound 2,3-butanedione is one of the most important diacetones and of great commercial interest due to its characteristic odour of butter (WELSH; MURRAY; WILLIANS, 1989).

Undecane was identified in the medium 7. According to Lee et al. (2003), undecane is one of the compounds responsible for the aroma of parmesan cheese. The compounds 2,3-butanedione and 2-nonenal are characteristic of peach aroma (DERAIL; HOFMANN; SCHIEBERLE, 1999).

Castor oil did not cause an increase in VOCs production. Heptanal and beta-ionone were the only compounds detected despite the known ability of castor oil to induce aroma production (CHRISTEN et al., 2000).

Some bioreaction conditions also induced the production of pigments (visually detected in media 1-6, 9 and 11). It is worth noting that beta-ionone was also detected in the runs in which the pigment was visually detected. This compound is recognised as the compound resulting from the oxidative degradation of alfa- and beta-carotene (WACHÉ et al., 2003). Beta-ionone has been reported as an aroma compound with fruit and flower aroma characteristics (COOPER; DAVIES; MENARY, 2003; BOVOLENTA et al., 2004). This compound was already found in the aroma of some fruits (IBANÉZ et al., 1998), mango fruit (KATAOKA; LORD; PAWLISZYN, 2000), orange (MAHATTANATAWEE et al., 2005), melon (LAMIKANRA; RICHARD, 2002), tomato (BEZMAN et al., 2003), and wine (SABON et al., 2002).

Table 6. Comparison of mean area (UA) of gamma-decalactone peak obtained by HS-SPME and Solvent Extraction (SE).

\begin{tabular}{lc}
\hline \multicolumn{1}{c}{ Run } & Mean area $\left(10^{6} \text { U.A. }\right)^{*}$ \\
\hline SE & $36.8 \pm 4.5^{\mathrm{c}}$ \\
SPME without salt addition & $47.1 \pm 1.5^{\mathrm{b}}$ \\
SPME with salt addition & $66.3 \pm 4.0^{\mathrm{a}}$ \\
\hline
\end{tabular}

${ }^{*}$ means \pm standard deviation. Values followed by same superscript letters are not significantly different $(\mathrm{p}<0.05)$ (Tukey Test). 
Table 7. Major compounds identified after HS-SPME extraction of the fermented media based on different supplements.

\begin{tabular}{|c|c|c|c|}
\hline Medium & Volatile compound & Match quality (\%) & Retention time (minute) \\
\hline \multirow[t]{9}{*}{1} & 1,4-butanediol & 81 & 2.5 \\
\hline & 1,2,2-trimethylciclopropylamine & 83 & 3.0 \\
\hline & Beta-ionone & 76 & 3.5 \\
\hline & 2,3-butanedione & 79 & 6.7 \\
\hline & Pentanal & 76 & 9.6 \\
\hline & Tetradecane & 78 & 12.1 \\
\hline & 4-octen-3-one & 76 & 27.0 \\
\hline & Propanoic acid & 71 & 28.6 \\
\hline & Octadecane & 77 & 29.2 \\
\hline \multirow[t]{2}{*}{2} & Beta-ionone & 87 & 3.5 \\
\hline & 1,2-bezenedicarboxylic acid & 92 & 29.2 \\
\hline \multirow[t]{2}{*}{7} & 2-ethyl-1-hexanol & 94 & 4.0 \\
\hline & Undecane & 93 & 5.0 \\
\hline 8 & 2-ethyl-1-hexanol & 94 & 6.5 \\
\hline 9 & Beta-ionone & 80 & 3.5 \\
\hline 10 & Heptanal & 75 & 3.0 \\
\hline 11 & Beta-ionone & 86 & 3.5 \\
\hline
\end{tabular}

\section{Conclusions}

The HS-SPME technique proved to be efficient for the volatile compound extraction from aqueous samples since it is able to extract almost two times more compounds than solvent extraction. The best sorption conditions for $100 \mu \mathrm{m}$ coated PDMS fibres were $60{ }^{\circ} \mathrm{C}$, for 30 minutes, without stirring, using a sample volume of $2.5 \mathrm{~mL}$ and a saturated $\mathrm{KCl}$ solution $(1: 10 \mathrm{vol} / \mathrm{vol})$. This technique presents advantages of being quick and practical requiring low sample volumes and thus suitable for the analysis of volatile compounds present in fermented broths, mainly in samples with low concentration of the analytes. In addition, it does not use solvents, concentrating samples instead of diluting them, as it often happens when solvent extraction is used.

The production of VOC was directly related to composition of the fermentation media, especially to the carbon source. Using $0.02 \%$ ricinoleic acid as carbon source, at $28{ }^{\circ} \mathrm{C}$, $160 \mathrm{rpm}$ and initial $\mathrm{pH} 6.0$, the following VOCs were found: 1,2,2-trimethylciclopropylamine; beta-ionone; 1,4-butanediol; 2,3-butanedione; pentanal; tetradecane; 2 -isononenal; 4-octen3-one; propanoic acid, and octadecane.

In fermentations carried out with the addition of ricinoleic acid and its derivatives and castor oil as precursors, the bioproduction of pigments was also observed. The Beta-ionone compound formed in these experimental runs is related to carotenoid oxidation. Synthesis of such VOC by bioreaction is promising due to its market value, its classification as natural, and low cost of the precursor.

\section{References}

BARRIONUEVO, W. R.; LANÇAS, F. M. Extração em fase sólida (SPE) e micro extração em fase sólida (SPME) de piretróides em água. Química Nova, v. 24, p. 172-175, 2001.

BEZMAN, Y. et al. Differential effects of tomate (Lycopersicon esculentum Mill) matrix on the volatility of important aroma compounds. Journal of Agriculture and Food Chemistry, v. 51, p. 722-726, 2003.

BLIN-PERRIN, C. et al. Metabolism of ricinoleic acid into $\gamma$-decalactone: $\beta$-oxidation and long chain acyl intermediates of ricinoleic acid in the genus Sporidiobolus sp. Microbiology Letters, v. 188 , p. 69-74, 2000.

BOVOLENTA, M. et al. A simple and efficient highly enantioselective synthesis of $\alpha$-ionone and $\alpha$-damascone. Journal of Organic Chemistry, v. 69, p. 8959-8962, 2004.

BUCHHOLZ, K.D.; PAWLISZYN, J. Optimization of solid-phase microextraction conditions for determination of phenols. Analytical Chemistry, v. 66, p. 160-167, 1994.

CAI, J.; LIU, B.; SU, Q. Comparison of simultaneous distillation extraction and solid-phase microextraction for the determination of volatile flavor components. Journal of Chromatography A, v. 930, p. 1-7, 2001.

CARASEK, E.; PAWLISZYN, J. Screening of tropical fruit volatile compounds using solid-phase microextraction (SPME) fibers and internally cooled SPME fiber. Journal of Agriculture and Food Chemistry, v. 54, p. 8688-8696, 2006.

CHRISTEN, P. et al. Characterization of volatile compounds produced by Rhizopus strains grown on agro-industrial solid wastes. Bioresource Technology, v. 71, p. 211-215, 2000. 
COOPER, C. M.; DAVIES, N. W.; MENARY, R. C-27 apocarotenoids in the flowers of Boronia megastigma (Nees). Journal of Agriculture and Food Chemistry, v. 51, p. 2384-2389, 2003.

DERAIL, C.; HOFMANN, T.; SCHIEBERLE, P. Differences in ley odorants of Handmade juice of Yellow-flesh Peaches (Prunus persica L.) induced by the workup procedure. Journal of Agriculture and Food Chemistry, v. 47, p. 4742-4745, 1999.

FIEDLER, K.; SCHUTZ, E.; GEH, S. Detection of microbial volatile organic compounds (MVOCs) produced by moulds on various materials. Journal of Hygiene Environmental Health, v. 204, p. 111-121, 2001.

GOUPRY, S. et al. Evaluation of Solid-Phase Microextraction for the isotopic analysis of volatile compounds produced during fermentation by lactic acid bacteria. Journal of Agriculture and Food Chemistry, v. 48, 2222-2227, 2000.

IBÁÑEZ, E. et al. Analysis of volatile fruit components by headspace solid-phase microextraction. Food Chemistry, v. 63, p. 281-286, 1998.

JANSSENS, L. et al. Production of flavours by microorganisms. Process Biochemistry, v. 27, p. 195-215, 1992.

KAFKAS, E. et al. Identification of volatile aroma compounds of strawberry wine using solid-phase microextraction techniques coupled with gas chromatography-mass spectrometry. Flavour and Fragance Journal, v. 21, p. 68-71, 2005.

KATAOKA, H.; LORD, H. L.; PAWLISZYN, J. Applications of solidphase microextraction in food analysis. Journal of Chromatography A, v. 880, p. 35-62, 2000.

LAMIKANRA, O.; RICHARD, O. Effect of storage on some volatile aroma compounds in Fresh-cut Cantaloupe Melon. Journal of Agriculture and Food Chemistry, v. 50, p. 4043-4047, 2002.

LEE, J. et al. Optimization of solid phase microextraction analysis for the headspace volatile compounds of Parmesan Cheese. Journal of Agriculture and Food Chemistry, v. 51, p. 1136-1140, 2003.

LIU, T. T.; YANG, T. S. Optimization of solid-phase microextraction analysis for studying change of headspace flavor compounds of banana during ripening. Journal of Agriculture and Food Chemistry, v. 50, p. 653-657, 2002.

MAHATTANATAWEE, K. et al. Identification and aroma impact of Norisoprenoids in Orange Juice. Journal of Agriculture and Food Chemistry, v. 53, p. 393-397, 2005.

MALLUCHOS, A. et al. Investigation of volatiles evolution during the alcoholic fermentation of grape must using free and immobilized cells with the help of solid phase miroextraction (SPME) headspace sampling. Journal of Agriculture and Food Chemistry, v. 50, p. 3840-3848, 2002.

MARTINS, P. S. O.; LEITE, S. G. F.; SILVA, A. J. R. Bioproduction of 6-pentyl-a-pirone by Trichoderma harzianum and its quantification after different methods of extraction. In: NATIONAL SYMPOSIUM OF BIOPROCESSES, 14., 2003, Florianópolis. Proceedings... Florianópolis: 2003.

MAURIELLO, G. et al. SPME-GC method as a tool do differentiate VOC profiles in Saccharomyces cerevisiae wine yeasts. Food Microbiology, v. 26, p. 256-252, 2009.

PAWLISZYN, J. Applications of solid phase microextraction. Cambridge: Royal Society of Chemistry, 1999.

PÉREZ, R. A. et al. Analysis of volatiles from Spanish honeys by solidphase microextraction and gas chromatography-mass spectrometry. Journal of Agriculture and Food Chemistry, v. 50, p. 2633-2637, 2002.

$\mathrm{SABON}$, I. et al. Determination of volatile compounds in grenache wines in relation with different terroirs in the rhone valley. Journal of Agriculture and Food Chemistry, v. 50, p. 6341-6345, 2002.

SALINAS, M. R. et al. Stir bar sorptive extraction applied to volatile constituents evolution during Vitis vinifera Ripening. Journal of Agriculture and Food Chemistry, v. 52, p. 4821-4827, 2004.

VERGNAIS, L. et al. Revaluation of Solid-Phase Microextraction for analysis of volatile metabolites produced by Staphylococci. Journal of Agriculture and Food Chemistry, v. 46, p. 228-234, 1998.

WACHÉ, Y. et al. Effect of cis/trans isomerism of $\beta$-carotene on the ratios of volatile compounds produced during oxidative degradation. Journal of Agriculture and Food Chemistry, v. 51, p. 1984-1987, 2003.

WELSH, F. W.; MURRAY, W. D.; WILLIANS, R. E. Microbiological and enzymatic production of flavor and fragrance chemicals. Critical Reviews in Biotechnology, v. 9, p. 105-169, 1989.

XIE, J.; SUN, B.; YU, M. Constituents of top fragrance from fresh flowers of Robinia Pseudoacacia L. occurring in China. Flavour and Fragance Journal, v. 21, p. 798-800, 2006.

XIONG, G. et al. Microwave-assisted headspace solid-phase microextraction for the analysis of bioemissions from Eucalyptus citriodora leves. Journal of Agriculture and Food Chemistry, v. 51, p. 7841-7847, 2003.

ZHANG, Z. M.; ZENG, D. D.; LI, G. K. The study of the aroma profile characteristics of durian pulp during storage by the combination sampling method coupled with GC-MS. Flavour and Fragance Journal, v. 22, p. 71-77, 2006. 